\title{
ERRATUM
}

\section{INTERACTIVE EFFECTS OF NITRATE AND PHOSPHATE SALTS, SUCROSE, AND INOCULUM CULTURE AGE ON GROWTH AND SESQUITERPENE PRODUCTION IN ARTEMISIA ANNUA HAIRY ROOT CULTURES}

\author{
P. J. WEATHERS,* D. D. HEMMAVANH, D. B. WALCERZ, R. D. CHEETHAM, AND T. C. SMITH \\ Departments of Biology/Biotechnology (P.J.W., R. D. C., T. C. S.), and Mechanical Engineering (D. B. W.), Worcester Polytechnic \\ Institute, 100 Institute Road, Worcester, Massachusetts 01609; BASF Corp., Plantation Street, Worcester, Massachusetts 01605 (D. D. H.) \\ (Received 9 December 1996; accepted 30 June 1997; editor H. E. Flores)
}

In the above paper, Figures 1 and 3 (on pages 308 and 310, respectively) were inadvertently transposed, but the figure legends are correct as printed. 